\title{
Construct The Management Accounting Information System Quality to Improve GCG Implementation
}

\author{
${ }^{1}$ RINI LESTARI, ${ }^{2 N U R F A H M I Y A T I, ~}{ }^{3}$ MAGNAZ LESTIRA OKTAROZA, ${ }^{4 B A Y U ~ P U T R A ~}$ \\ ${ }^{134}$ Accounting Study Program, ${ }^{2}$ Economics and Development Study Program \\ Faculty of Economics and Business, Universitas Islam Bandung , Jl.Taman Sari No 1 \\ email: ${ }^{1}$ unirinilestari@gmail.com
}

\begin{abstract}
This study is motivated by various cases occurred in Sharia banking institutions related to the many cases of embezzlement of customer funds and the provision of fictitious financing. Such cases show strong indication of corruption in the institutions which in turn makes the level of Non-Performing Financing (NPF) higher and causes the company's performance to get worse. These problems can be caused by the weak implementation of Good Corporate Governance (GCG). This study aims to examine the construction of a management accounting information system quality (KSIAM) model, which is seen from the factor that influences it such as the Islamic organizational culture, the effectiveness of internal control, and business strategy. Furthermore, this research also examines the effect of KSIAM towards the implementation of Good Corporate Governance (GCG) in Sharia banking institutions in Bandung, Indonesia. This study uses a quantitative research approach, gathers data using survey methods, and applies SEM/PLS as statistical analysis techniques. The study population is all Sharia Banking Institutions in Bandung, with the target population of all Sharia banks in the city of Bandung (42 banks) in the 2018-2019 periods. The sampling technique used is a nonprobability sampling technique with the type of convenience sampling. The results show that Islamic organizational culture and the effectiveness of internal control have not been able to build a KSIAM model, while a business strategy is able to build a KSIAM. Moreover, KSIAM has a significant effect on the implementation of GCG in Sharia banking institutions in Bandung.
\end{abstract}

Keywords: islamic organizational culture, management accounting information system, the effectiveness of internal control

\section{Introduction}

Recently, the development of Sharia banking is still far from what it used to be expected. Regardless of the huge potential market, if we look at the Muslim population which is the largest in the world, it does not guarantee the rapid pace of Sharia banking development. In fact, the financial performance of Sharia banking has declined in recent years. This is due to the poor implementation of GCG by Sharia banking which led to many cases of problematic financing (Supriyanto, 2018). Moreover, the Non-Performing Financing (NPF) from 2014 to 2018 showed a significant decrease in Sharia Banking performance due to the increase of NPF rate (from $4.95 \%$ to $5.21 \%$ ).

The decline in sharia banking performance is caused by the poor implementation of GCG in Sharia banking, such as the case of fictitious financing worth Rp.1.1 trillion by the authorized officials at Bank Syariah Mandiri (Saiman, 2018). In BJB Syariah, there has been an alleged corruption case worth Rp566 billion (Falatehan, 2018). Next is a problematic financing case of Rp.1.3 trillion at Bank Panin Dubai Syariah (Djarot, 2019), and In 2019, there has been a case of embezzlement of customer funds amounting to Rp.35 billion at Bank Syariah Mandiri (MAKI, 2019).

Received: March 19, 2021, Revision: May 09, 2021, Accepted: June 14, 2021

Print ISSN: 0215-8175; Online ISSN: 2303-2499. DOI:https://doi.org/10.29313/mimbar.v37il.7763

Accredited Sinta 2 based on the decree No.10/E/KPT/2019 until 2024. Indexed by DOAJ, Sinta, Garuda, Crossreff, Dimensions 
The cases mentioned above prove that Sharia banking management has violated the principle of responsibility in GCG, showed an aggressive and risky action that ultimately leads to criminal acts of corruption that can cause losses to this country, Indonesia. The poor implementation of GCG in Sharia banking is caused by the low quality of the management accounting information system (SIAM) (Lestari, Sofianty and Sukarmanto, 2018).

Meanwhile, according to the past research, the low quality of SIAM in Sharia banking is because the SIAM components and the number of customer complaints were not fully integrated (Galileoni and Lestari, 2017). Other research stated that the quality of SIAM can be caused by the weak application of organizational culture (Rachman, Adrian and Husniah, 2019), ineffective internal control (Majid et al., 2020), and lack of business strategy (Puspitawati and Susanto, 2018). Several previous research results explain that the quality of SIAM (KSIAM) has a positive effect on GCG (Uyar, Gungormus and Kuzey, 2017). There are a lot of factors that can affect the formation of KSIAM, one of them is organizational culture (Susanto and Meiryani, 2018). Furthermore, Napitulu also stated that organizational culture is very important to improve the quality of SIAM (Napitupulu, 2015; Aldegis, 2018). Likewise with HA, (2020); Nurliyani, Darma and Ikhsan (2020); Zaena (2016); ElKelish and Rickards (2018) also stated that the quality of SIAM is influenced by organizational culture, as well as Islamic organizational culture. As stated by (Satria and Yuliansyah, 2020), there is a positive influence between the application of Islamic organizational culture to the SIAM and its impact on being able to improve the performance of Sharia banking. The effectiveness of internal control affects KSIAM (Susanto, 2017). Meanwhile, Napitupulu (2020) and (Lam, 2017) stated that adequate internal control can improve the efficient functioning of an information system.

Furthermore, Alamri (2018) and Pasch (2019) showed that the implementation of business strategy is very important to improve the implementation of management accounting system. This study aims to explain how the construction of the KSIAM model is seen from the factors that influence it, which are the culture of Islamic organizations, the effectiveness of internal control and business strategy, and also to examine the effect of
KSIAM on the implementation of GCG in Sharia banking institutions in Bandung. Next, this research is expected to contribute to the formation of KSIAM model design that can improve the implementation of GCG so that Sharia banking could be more trusted and sustainable. These factors are what make this research different from previous studies.

Organizational culture is a pattern of behavior and thought that characterizes values that are shared and accepted in an organization which will becomea characteristic that distinguishes one organization from another (McShane and Glinow, 2017). Robbins and Judge (2019) categorized seven characteristics of organizational culture with the following structure: innovation and risk-taking, attention to detail, outcome orientation, people orientation, team orientation, and aggressiveness. Furthermore, the measurement of Islamic organizational culture variables will be based on Islamic values which are reflected in the characteristics of the Prophet Muhammad SAW, namely Shiddiq, Amanah, Tabligh, and Fathonah (Kadir and Muh, 2015).

The effectiveness of internal control can be defined as the effectiveness of a process that affected by the board of directors, management, and employees which is designed to provide convincing assurance that organizational goals will be achieved (Susanto, 2017). Next, Laudon and Laudon (2020) stated that the implementation of effective security and control can improve the quality and reliability of information systems. The effectiveness of internal control can be measured from general control and application controls (Susanto, 2017; Romney and Steinbart, 2018; Laudon and Laudon, 2020).

Business strategy is a series of actions planned by the company to achieve the company's vision, mission, and goals so that it can achieve its competitive advantage (Nasieku and Githinji, 2016; Wheelen et al., 2018). Business strategy can be measured through: defenders, which focus on the efficiency of operating activities; prospectors, which focus on product innovation and market opportunities; analyzers, which focus on efficiency in stable areas; and reactors, which perform ineffective responses to environmental pressures (Wheelen et al., 2018).

Quality of SIAM can be interpreted as a form of statement regarding the 
conditions whereas SIAM can produce useful information for managers in carrying out the management process (Hilton and Platt, 2016). Track of the SIAM can be measured from several dimensions, namely integration, accessibility, flexibility, formalization, and media richness (Novianty, 2019; Robbins and Judge, 2019).

The implementation of Good Corporate Governance (GCG) as regulated in POJKNo.4/ POJK.03/2015 is the implementation of bank governance that applies the principles of openness, accountability, responsibility, independence, and fairness. The implementation of good Sharia bank institutional management is important to create a healthy, strong, and trustworthy banking industry so that it can achieve a competitive advantage in winning the competition (Novatiani et al., 2018).

The study conducted by Lestari, Sofianty and Sukarmanto (2018) proved that GCG implementation is influenced by the quality of SIAM. Furthermore, it can be said that the weak implementation of GCG can be caused by the low quality of SIAM. The quality of SIAM that produces good financial reporting has a positive effect on GCG (Uyar, Gungormus and Kuzey, 2017). This is in line with the previous research by Kasasbeh (Kasasbeh, 2017) which discovered that GCG supports the effectiveness of SIAM. SIAM produces transparent information as needed by the company to achieve good GCG (Mariana and Maria, 2016; Lestari, 2020; Musah and Adutwumwaa, 2021). Meanwhile, the research conducted by Susanto (Susanto, 2017) stated that the quality of SIA affects good study program governance. However, sometimes SIAM produces information which is not coherent and is not relevant to the needs of decision-makers (Al-Attar, 2021). To produce the information needed by decisionmakers, it requires the quality of SIAM which is influenced by organizational culture (Susanto and Meiryani, 2018). Moreover, organizational culture is very important to improve the quality of SIAM (Aldegis, 2018; Napitupulu, 2018). Likewise, Zaena (2016); ElKelish and Rickards (2018); HA (2020); Nurliyani, Darma and Ikhsan (2020) stated that the quality of SIAM is influenced by organizational culture and also the culture of Islamic organizations. This was also revealed by (Satria and Yuliansyah, 2020) study which found that the application of Islamic organizational culture has a positive effect on management accounting information systems and its impact can improve the performance of Sharia banking in Indonesia.

Besides, the quality of SIAM is also influenced by the effectiveness of internal control (Susanto, 2017). Lam (2017) and Napitupulu (2020) stated that adequate internal control is needed to ensure the implementation of an information system function that facilitates the process of achieving company goals. The results of the study that support this statement include (Bangsa, 2018; Majid et al., 2020) which indicated that there is a significant influence of internal control on the efficiency of the accounting information system. The quality of SIAM, in addition to organizational culture and the effectiveness of internal control, is also influenced by business strategy (Puspitawati and Susanto, 2018). Furthermore, Alamri (2018) and Pasch (2019) found that the application of business strategy is very important to improve management accounting system practices so

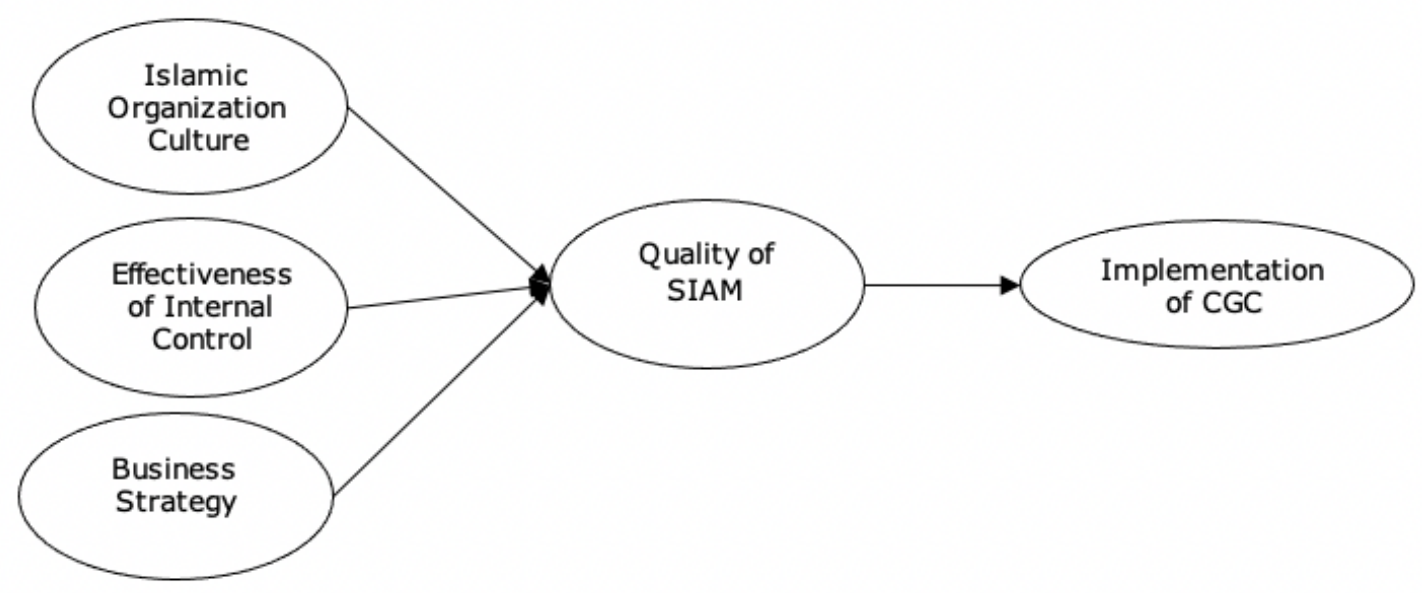

Figure 1. Research Model 
that companies can achieve their competitive advantage. The following is a picture 1 of the research model

\section{Research Methodology}

This research used a quantitative approach with a survey method. A quantitative approach is an approach for testing objective theories by examining the relationships among variables (Creswell and Creswell., 2017). The survey method provides a quantitative or numeric description of trends, attitudes, and behavior, or opinions of a population by studying a sample of that population (Sekaran and Bougie, 2016; Creswell and Creswell., 2017).

The research procedures that relate to the quantitative research approach in this study are determining the population and research samples, explaining the operationalization of the variables, and explaining the data collection techniques and data analysis techniques used so that the hypothesis in the study can be tested to answer the research problem.

The population in this study is all Sharia Banking institutions in Indonesia with a target population of all Sharia banks in Bandung in the period of 2018-2019 totaling 42 institutions. In this study, all target populations will be sampled using a non-probability sampling technique with a convenience sampling method (Sekaran and Bougie, 2016). This convenience sampling method is determined by calculating how many companies (Sharia banks) are willing to return the questionnaires that have been distributed for approximately two to three months and a half (from December to early March 2020).

The operationalization of the variables in this study is explained as follows: Islamic organizational culture variables are measured by the following dimensions: 1) Amanah (honest or trustworthy) as measured by indicators: carry out the work assigned, obey the obligations, 2) Shiddiq (true) as measured by indicators: doing the job right, no mistakes, getting the job done on time, 3 ) Tabligh (convey) as measured by indicators: reporting the results of work, not hiding the actual results or changing them, 4) Fathonah (intelligent) as measured by indicators: innovate, have ideas, increase the knowledge.
The effectiveness of internal control variables are measured by dimensions: 1 ) General control as measured by indicators: control of the organization, control of assets and equipment, documentation control and data security control; and 2) Application control as measured by indicators: input control, process control and control of the output. Business strategy variables are measured by the following dimensions: 1) Defenders as measured by indicators: the company uses resources as needed, the company does not add services as the current development, and the price offered is cheaper than competitors; 2) Prospector as measured by indicators: the company makes product innovations in line with consumer needs and setting targets each month to get significant sales results; 3) Analyzer as measured by indicators: a widespread market segment and making innovation in an era of change but always efficient and stable' 4) Reactor as measured by indicators: implementation of inconsistent strategies according to planning.

Quality of SIAM variables are measured by the following dimensions: 1) Integration as measured by indicators: integration between system of components, and integration between system of subcomponents; 2) Flexibility as measured by indicators: able to adjust user needs and able to adapt to changing conditions; 3 ) Accessibility as measured by an indicator: can be accessed easily; 4) Formalization as measured by an indicator: every activity has formal (written) rules; and 5) Media richness as measured by an indicator: using various alternative media to simplify and speed up communication.

The implementation of GCG variables is measured by several dimensions: 1) Transparency; 2) Accountability; 3) Responsibility; 4) Independency; and 5) Fairness. The data collection is a systematic and standard procedure for obtaining the data used. The collection techniques used in this study were 1) questionnaires, which were directly given to the operational manager of the Sharia bank in Bandung; 2) in-depth interviews; and 3) documentation. Based on the results of distributing questionnaires to 42 Sharia banking institutions in Bandung, only 16 of them were willing to respond and return the questionnaires with a total number of respondents as many as 51 people. The data analysis techniques used were 1) Testing research instruments through a) 
validity testing, and b) reliability testing; 2) Hypothesis testing using statistical techniques, namely SEM-PLS to test the factors that could develop the construction of SIAM quality model and to prove how the quality of SIAM affects the implementation of GCG.

\section{Result and Discussion}

In this study, there were 20 variables with 44 manifest variables. The latent variable of Islamic organizational culture consists of 4 manifest variables, the effectiveness of internal control consists of 2 manifest variables, the business strategy consists of 4 manifest variables, the KSIAM consists of 5 manifest variables, and the implementation of GCG consists of 5 manifest variables.
Using the second-order estimation method from Partial Least Square, the full pathway of the influence of Islamic organizational culture, the effectiveness of internal control and business strategy on the quality of management accounting information systems is obtained and its implications for the implementation of GCG is shown in figure 2 .

Through the factor weighted values, as shown in Figure 2, the validity of each indicator can be assessed as well as testing the reliability of the constructs of the variables studied. The indicators that have a loading factor less than 0.50 will be reduced from the model, while the composite reliability that is considered satisfactory is greater than 0.70 . The following shows the measurement model of each variable used in this study.

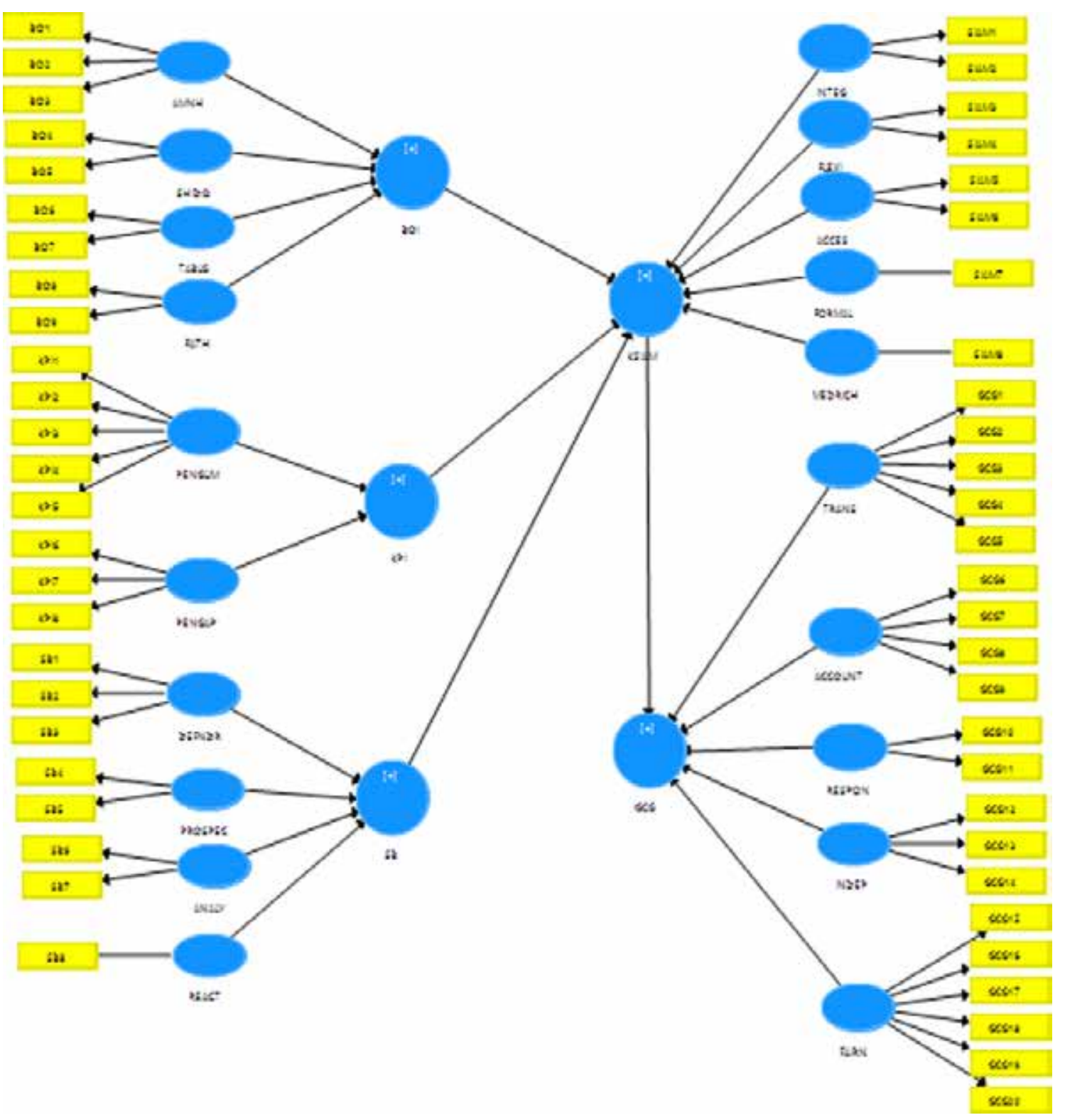

Figure 2. Full model path diagram 
First-Order Analysis Validity Test Result

Based on the results of data processing using Smart PLS 3.0 software, the results of testing each variable using the first-order confirmatory factor analysis is presented in the following table.

Table 1

\section{Summary of First-Order Validity Test}

\begin{tabular}{|c|c|c|c|c|}
\hline Indicators & $\begin{array}{l}\text { Factor } \\
\text { Weight- } \\
\text { ed val- } \\
\text { ues }\end{array}$ & $\mathbf{t}$ & CR & AVE \\
\hline \multicolumn{5}{|l|}{ Islamic Organizational Culture Variables } \\
\hline $\begin{array}{l}\text { Really carry out the work assigned, not absent from the } \\
\text { obligations imposed }\end{array}$ & 0.611 & 2,961 & 0.767 & 0.652 \\
\hline $\begin{array}{l}\text { Doing the job right, no mistakes, getting the job done on } \\
\text { time }\end{array}$ & 0.769 & 11,969 & 0.844 & 0.644 \\
\hline $\begin{array}{l}\text { Report the work results, do not hide the actual results or } \\
\text { change them }\end{array}$ & 0.821 & 9,184 & 0.752 & 0.603 \\
\hline Innovate, have ideas, increase the knowledge & 0.871 & 15,332 & 0.776 & 0.636 \\
\hline \multicolumn{5}{|l|}{ Internal Control Effectiveness Variables } \\
\hline Organizational control & 0.840 & 4,368 & 0.794 & 0.658 \\
\hline Control of assets and equipment & 0.782 & 2,999 & & \\
\hline \multicolumn{5}{|l|}{ Documentation control } \\
\hline \multicolumn{5}{|l|}{ Data security control } \\
\hline Input control & 0.809 & 4,372 & 0.767 & 0.622 \\
\hline Process control & 0.769 & 5,321 & & \\
\hline \multicolumn{5}{|l|}{ Output control } \\
\hline \multicolumn{5}{|l|}{ Business Strategy Variable Measurement Model } \\
\hline Companies use resources as needed & 0.769 & 11,969 & 0.844 & 0.644 \\
\hline $\begin{array}{l}\text { The company does not add services as the current devel- } \\
\text { opment }\end{array}$ & 0.798 & 14,542 & & \\
\hline The price offered is cheaper than competitors & 0.839 & 16,854 & & \\
\hline $\begin{array}{l}\text { The company makes product innovations in line with con- } \\
\text { sumer needs }\end{array}$ & 0.821 & 9,184 & 0.752 & 0.603 \\
\hline $\begin{array}{l}\text { Set a target each month in order to get significant sales } \\
\text { results }\end{array}$ & 0.730 & 4,206 & & \\
\hline A widespread market segment & 0.919 & 34,117 & 0.903 & 0.824 \\
\hline $\begin{array}{l}\text { Making innovation in an era of change but always efficient } \\
\text { and stable }\end{array}$ & 0.896 & 26,616 & & \\
\hline Strategy implementation is not consistent according to plan & 0.871 & 15,332 & 0.776 & 0.636 \\
\hline \multicolumn{5}{|c|}{ Quality Variable Management Accounting Information Systems } \\
\hline Integration between system components & 0.955 & 14,675 & 0.854 & 0.746 \\
\hline Integration between system subcomponents & 0.959 & 34,106 & & \\
\hline Able to adjust user needs & 0.937 & 26,816 & 0.907 & 0.829 \\
\hline Able to adapt to changing conditions & 0.929 & 31,290 & & \\
\hline The information system used is easy to use & 0.939 & 52,141 & 0.839 & 0.723 \\
\hline Easy to access application software as needed & 0.905 & 11,284 & & \\
\hline Every activity has formal rules & 1.00 & - & - & - \\
\hline $\begin{array}{l}\text { The information system used has various alternative media } \\
\text { to simplify and speed up communication }\end{array}$ & 1.00 & - & - & - \\
\hline
\end{tabular}




\begin{tabular}{|c|c|c|c|c|}
\hline Indicators & $\begin{array}{l}\text { Factor } \\
\text { Weight- } \\
\text { ed val- } \\
\text { ues }\end{array}$ & $\mathbf{t}$ & CR & AVE \\
\hline \multicolumn{5}{|l|}{ Good Corporate Governance Implementation } \\
\hline Disclose information in a timely manner & 0.820 & 15,525 & 0.901 & 0.646 \\
\hline Disclose information clearly & 0.855 & 15,165 & & \\
\hline Internal supervision and control system & 0.853 & 26,315 & & \\
\hline Compliance status, system, and implementation of GCG & 0.921 & 50,922 & & \\
\hline $\begin{array}{l}\text { The principle of transparency which does not reduce the pro- } \\
\text { visions on bank secrecy }\end{array}$ & 0.851 & 22,123 & & \\
\hline $\begin{array}{l}\text { Organizational responsibilities are in line with the bank's } \\
\text { vision and mission }\end{array}$ & 0.750 & 11,628 & 0.863 & 0.611 \\
\hline $\begin{array}{l}\text { Organizational responsibilities are aligned with bank goals } \\
\text { and strategies }\end{array}$ & 0.845 & 20,890 & & \\
\hline Understanding of the role of GCG implementation & 0.776 & 12,511 & & \\
\hline $\begin{array}{l}\text { The precautionary principle is in accordance with the appli- } \\
\text { cable regulations }\end{array}$ & 0.810 & 13,265 & 0.717 & 0.560 \\
\hline Care for the environment and social responsibility & 0.682 & 6,291 & & \\
\hline Avoiding unnatural domination by stakeholders & 0.849 & 20,552 & 0.887 & 0.723 \\
\hline $\begin{array}{l}\text { Does not affect unilateral interests and is free from conflicts } \\
\text { of interest }\end{array}$ & 0.868 & 31,665 & & \\
\hline Objective decisions and free from pressure from any party & 0.833 & 13,721 & & \\
\hline Pay attention to the interest of all stakeholders & 0.766 & 15,595 & 0.934 & 0.702 \\
\hline Provide opportunities to stakeholders & 0.832 & 19,708 & & \\
\hline $\begin{array}{l}\text { Stakeholder has access to information in accordance with } \\
\text { the principle of openness. }\end{array}$ & 0.791 & 12,388 & & \\
\hline
\end{tabular}

source: data processed, 2021

Based on the results of the firstorder confirmatory factor analysis, it can be seen that the factor weight value of each indicator is greater than 0.50 . This means that all indicators are valid as a measuring tool for their respective dimensions. Then the composite reliability (CR) value of each dimension is greater than 0.70, which indicates that the indicators have consistency in measuring their respective dimensions. Furthermore, the average value of extracted variance (AVE) for each dimension is greater than 0.5 , which means there is no convergent validity problem in the model being tested.

\section{Second-Order Analysis Validity Test Results and Discussions}

Based on the results of data processing using Smart PLS 3.0 software, the results of testing each variable using the second-order analysis is presented in the following table. Based on the results of the second-order analysis, it can be seen that the regression coefficient values of all dimensions are significant. This means that all these dimensions are dimensions that make up the latent variables of each variable.

\section{Structural Model}

The structural model in this study involves three exogenous latent variables which are Islamic organizational culture, the effectiveness of internal control, and business strategy, and also two endogenous latent variables which are quality management accounting information systems and Good Corporate Governance (GCG) implementation. The results of calculating standardized path coefficients for the structural model of the influence of Islamic organizational culture, the effectiveness of internal control, and business strategy on the quality of management accounting information systems and their implications for the implementation of Good Corporate Governance (GCG) are shown in the following figure 3. 
Table 2

Summary of Second-Order Validity Test Results

\begin{tabular}{lllll}
\hline Dimension & $\begin{array}{l}\text { Regression Co- } \\
\text { efficient }\end{array}$ & T R2 & \\
\hline Islamic Organizational Culture & & & \\
Amanah (honest or trustworthy) & 0.208 & 5,526 & 0.995 \\
Shiddiq (true) & 0.416 & 7,891 & \\
Tabligh (convey) & 0.190 & 4,614 & \\
Fathonah (intelligent) & 0.296 & 7,197 & \\
Effectiveness of Internal Control & & & \\
General control & 0.596 & 4,073 & 0.997 \\
Application control & 0.649 & 4,776 & \\
Business Strategy & & & \\
Defender & 0.208 & 5,526 & \\
Prospector & 0.341 & 7,891 & 0.999 \\
Analyzer & 0.290 & 4,614 & \\
Reactor & 0.181 & 5,845 & \\
Accounting Information Systems Quality Measurement & & & \\
Integration & 0.801 & 15,808 & \\
Flexibility & 0.871 & 28,129 & \\
Accessibility & 0.856 & 29,970 & 0.255 \\
Formalization & 0.488 & 5,106 & \\
Media Richness & 0.6202 & 8,182 & \\
Good Corporate Governance Implementation & & & \\
Transparency & 0.896 & 33,004 & \\
Accountability & 0.881 & 26,127 & 0.392 \\
Responsibility & 0.765 & 14,907 & \\
Independency & 0.888 & 37,274 & \\
Fairness & 0.928 & & \\
\hline & & & \\
\end{tabular}

source: data processed, 2021

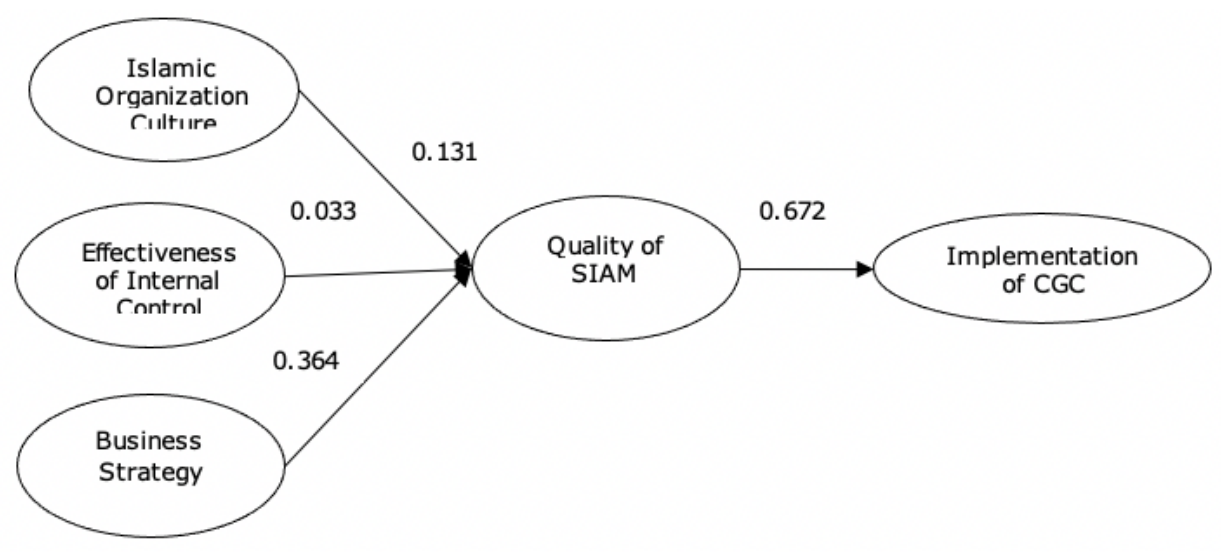

Figure 3. Coefficients of Standardized Structural Model

The Influence of Islamic Organizational Culture on the Quality of Management Accounting Information Systems

Islamic organizational culture is hypothesized to affect the quality of management accounting information systems. The following shows the results of the significance test of this hypothesis (table $3)$.

Based on the table above, it can be 
Table 3

Testing Results of the Effect of Islamic Organizational Culture on KSIAM

\begin{tabular}{cccc}
\hline Path Coefficient & t-count & t-critical & Ho \\
\hline 0.131 & 0.630 & 1.96 & Received \\
\hline \multicolumn{4}{c}{ source: data processed, 2021 }
\end{tabular}

seen that the $t$-count value of the Islamic organizational culture variable is 0.630 , which is smaller than the t-critical value (1.96). Because the value oft-count is smaller than the t-critical value, with an error level acceptance for $5 \%$, it was decided to accept $\mathrm{H}_{0}$. Thus, based on the test, it can be concluded that Islamic organizational culture has no significant effect on the quality of management accounting information systems in Sharia banks. The results of this study provide empirical evidence that Islamic organizational culture has not been able to improve the quality of management accounting information systems, even though the direction of the path coefficient is positive.

\section{The Effect of Internal Control Effectiveness on Quality of Management Accounting Information Systems}

The effectiveness of internal control is hypothesized to affect the quality of management accounting information systems. The following table shows the results of the significance test of this hypothesis:

Table 4

Results of Testing the Effect of Internal Control Effectiveness on the KSIAM

\begin{tabular}{cccc}
\hline Path Coefficient & t-count & t-critical & Ho \\
\hline 0.033 & 0.935 & 1.96 & Received \\
\hline \multicolumn{4}{c}{ source: data processed, 2021 }
\end{tabular}

Based on the table above, it can be seen that the $t$-count value of the internal control effectiveness variable is 0.935 , which is smaller than the t-critical (1.96). Because the value of $t$-count is smaller than the $t$-critical value, then at an error level of $5 \%$, it was decided to accept $\mathrm{H}_{0}$. Thus, based on the test, it can be concluded that the effectiveness of internal control has no significant effect on the quality of management accounting information systems in Sharia banks. The results of this study provide empirical evidence that the effectiveness of internal control has not been able to improve the quality of management accounting information systems, although this is based on a positive path coefficient.

The Effect of Business Strategy on the Quality of Management Accounting Information Systems

Business strategy is hypothesized to affect the quality of management accounting information systems. The following shows the results of the significance test of this hypothesis:

Table 5

The Results of Testing the Effect of Business Strategy on the KSIAM

\begin{tabular}{cccc}
\hline Path Coefficient & t-count & t-critical & Ho \\
\hline 0.364 & 2,351 & 1.96 & Rejected \\
\hline
\end{tabular}

Based on the table above, it can be seen that the $t$-count value of the business strategy variable is 2.351 , which is greater than the t-critical value (1.96). Because the value of $t$-count is greater than the $t$-critical value, at an error level of $5 \%$, it was decided to reject $\mathrm{H}_{0}$. Thus, based on the test, it can be concluded that business strategy has a significant effect on the quality of management accounting information 
systems in Sharia banks. The results of this study provided empirical evidence that business strategy can improve the quality of management accounting information systems with a positive direction. The Effect of the Quality of Management
Accounting Information Systems on

\section{the Implementation of Good Corporate Governance}

The quality of Management Accounting Information Systems is hypothesized to affect the implementation of good corporate governance. The following shows the results of the significance test of this hypothesis:

Table 6

The Results of Testing the Effect of the KSIAM on the Implementation of GCG

\begin{tabular}{cccc}
\hline Path Coefficient & t-count & t-critical & Ho \\
\hline 0.672 & 3,921 & 1.96 & Rejected \\
\hline
\end{tabular}

Based on the test results, it can be seen that the $t$-count value of the KSIAM on the implementation of good corporate governance is 3.921 , which is greater than the t-critical value (1.96). Because the value of $\mathrm{t}$ is greater than the $\mathrm{t}$-critical level, at an error level of $5 \%$, it was decided to reject $\mathrm{Ho}$. Based on the test results, it can be concluded that the quality of management accounting information systems has an effect on the implementation of GCG. The SIAM has an effect of $51.62 \%$ on the implementation of GCG, while the remaining $49.38 \%$ is influenced by other factors not examined in this study.

\section{Discussion}

In the previous section, the results of hypothesis testing have been explained. Meanwhile, in this section, a discussion for further implications will be carried out based on the results of hypothesis testing to provide a more comprehensive explanation of the research problem. Based on the results of the structural model test, it can be explained that the factors or the variables that could develop the construction of the SIAM quality model are Islamic organizational culture, organizational effectiveness, and business strategy. Further from this research, it is known that Islamic organizational culture has no significant effect on the quality of SIAM. The results of hypothesis testing provide empirical evidence which shows that Islamic organizational culture has not been able to improve the quality of SIAM. This means that Islamic organizational culture has not been able to develop the construction of the SIAM quality model. The results of this study contradict the research conducted by Satria and Yuliansah (Satria and Yuliansyah, 2020) which showed that the application of Islamic organizational culture was able to improve company performance moderated by management accounting information systems.

Research by Satria and Yuliansah showed that the Islamic organizational culture has a positive correlation to the management accounting information system. The research was conducted at Sharia banking institutions in Indonesia within a certain period with the number of respondents who filled out the questionnaire as many as 168 respondents out of 589 targeted respondents. Likewise, the results of research conducted by Ekawati et al (2019) showed that the application of organizational culture from an Islamic perspective and management accounting information systems has a positive effect on the performance of Sharia banking in Indonesia. Subsequent research, namely research conducted by Egdair and Abdelsalam (2020), shows how the implementation of organizational culture in Sharia banking institutions in Libya.

The results of these studies indicate the importance of implementing organizational culture in improving the quality of Sharia banking services. However, different results have been generated from this study that the Islamic organizational culture has no significant effect on the quality of SIAM in Sharia banking institutions in the city of Bandung. These possibilities occurred due to the minor size of the sample, as there were only 15 Sharia banking institutions with a total of 45 respondents who are willing to fill out the questionnaire. Furthermore, it 
can be explained that the limitation in the results of this study is based on the results of respondent's responses and depth interviews with several Sharia banking managers in Bandung, whereas the managers have not been able to be fully innovative by creating ideas and increase knowledge in improving the quality of SIAM. In other words, individual managers do not try their best to get used to producing new techniques or ways with new ideas and new knowledge to complete their work properly, as this case could lead to the weak application of organizational culture in improving the quality of SIAM. The results of this study support the results of previous research in 2019 by Lestari, Sofianty, and Kuntorini (2019) which state that the application of organizational culture does not affect the quality of management accounting information systems improvements. Furthermore, overall, the results of this study are limited only to Sharia banking institutions in Bandung, so that further research is needed with a larger number of samples so that the results of the research can be generalized widely. Moreover, from the structural model testing, it was proven that the effectiveness of internal control was not able to significantly improve the quality of SIAM in Sharia banking institutions in Bandung. This means that the effectiveness of internal control has not been able to develop the construction of the SIAM quality model.

In addition to the number of samples that are still at the minimum size, the effectiveness of internal control in Sharia banking institutions in Bandung also had many weaknesses, especially in the aspect of general control related to organizational control activities, assets and equipment, documentation, and data security, therefore it is unable to improve the SIAM quality. SIAM quality enhancement does require the effectiveness of internal control as said by Lam (2017); Bangsa (2018); Napitupulu (2020), in order to achieve the company goals.

Thus, the results of this study are not in line with all the research results previously mentioned. In this case, the result of this research could provide wider factors and opportunities for other researchers to carry out more in-depth investigations of the effectiveness of internal control variables in improving the quality of SIAM. Furthermore, the results of model testing provide empirical evidence where the business strategy has a significant effect on the quality of SIAM. This implied that business strategy can improve the quality of SIAM. Hence, this means that business strategy has been able to develop the construction of the SIAM quality model. The results of this study are in line with the research conducted by Alamri (2018) and Pasch (2019), which shows that the application of business strategy is very important to improve management accounting system practices so that companies can achieve their competitive advantage.

Eventually, the results of the structural model test indeed prove that the quality of SIAM can improve the implementation of GCG in Sharia banking institutions in Bandung. It can be stated that the quality of SIAM has an important role in improving the implementation of GCG in Sharia banking institutions in the city of Bandung. The implementation of GCG is formed through the principles of GCG, namely transparency, accountability, responsibility, independence, and fairness which have been carried out very well, so that the managers as representatives of the company can control company activities, especially in increasing integration, flexibility, accessibility, formalization and high ability in using media so that they could actualize the quality of SIAM.

The implementation of GCG which is able to improve the quality of SIAM can make Sharia banking institutions become healthy, strong, and trustworthy institutions. This finding is in line with the results of research conducted by Kasasbeh (2017) and Uyar, Gungormus and Kuzey (2017), as well as (Musah and Adutwumwaa, 2021) findings. However, the research results cannot be broadly generalized into the general area as the result is only applicable to Sharia banking institutions in Bandung.

Therefore, further research with a broader and wider generalization area is required so it could strengthen the theories regarding SIAM quality as a development of science in the future. Based on the discussion that we have conducted as a research team, it can be proven empirically that the variables of Islamic organizational culture and the effectiveness of internal control have not been able to form a quality model for SIAM to improve the implementation of GCG in Sharia banking institutions in Bandung. The model construction that we have done should be re-examined with deeper investigation 
through broadening the generalization area by expanding the target population and using different research methods, such as qualitative method or a combination of quantitative and qualitative.

\section{Conclusion}

The construction of the KSIAM model is seen from the factors that influence it, namely the culture of Islamic organizations, the effectiveness of internal control, and business strategy. Further, this research shows that the Islamic organizational culture and the effectiveness of internal control have not been able to build a KSIAM model, while in other areas, the business strategy can build a KSIAM model in Sharia banking institutions in Bandung. The capability of business strategy to build KSIAM could be proven by empirical evidence that the implementation of a well-developed business strategy could improve the quality of SIAM in Sharia banking institutions in Bandung.

This research also concludes that KSIAM has a significant effect on the implementation of GCG. This case is reflected from the KSIAM model which is able to improve the implementation of GCG in Sharia banking institutions in Bandung.

\section{Acknowledgment}

This research cannot be carried out optimally if it is not fully supported by funding from the Institution of Research and Community Services at Bandung Islamic University. Our team is very grateful to the Chairman of the Institution of Research and Community Services at the Islamic University of Bandung. We also do not forget to express our deepest gratitude to the Dean of the Faculty of Economics and Business and the Chairman of the Accounting Study Program at the Islamic University of Bandung for giving strong motivation and fully supporting the implementation of this research. Hopefully, this research will continue so that it can advance Bandung Islamic University by increasing research dharma.

\section{References}

Al-Attar, K. A. A. (2021) 'The effect of accounting information system on corporate governance', Accounting, 7, pp. $99-110$.
Alamri, A. M. (2018) 'Strategic Management Accounting and the Dimensions of Competitive Advantage: Testing the Associations in Saudi Industrial Sector', International Journal of Academic Research in Accounting, Finance and Management Sciences, 8(2), pp. 48-64.

Aldegis, A. M. (2018) 'Impact of Accounting Information Systems' Quality on the Relationship between Organizational Culture and Accounting Information in Jordanian Industrial Public Shareholding Companies', International Journal of Academic Research in Accounting, Finance and Management Sciences, 8(1), pp. 70-80.

Bangsa, I. N. (2018) 'The Effect of Internal Control Systems, Accounting Systems on the Quality of Financial Statements Moderated by Organizational Commitments', Accounting Analysis Journal, 7(2), pp. 127-134.

Busco, C. and Scapens, R. W. (2011) 'Management accounting systems and organizational culture', Qualitative Research in Accounting \& Management, 8(4), pp. 320-357.

Creswell, J. W. and Creswell., J. D. (2017) Research design: Qualitative, quantitative, and mixed methods approaches, Sage publications. USA.

Djarot, S. (2019) OJK is monitoring the Panin Dubai Syariah fictitious credit case. Available at: http://kontan.co.id (Accessed: 7 November 2019).

Egdair, I. M. M. and Abdelsalam, M. K. (2020) 'The Impact of Corporate Culture on Service Quality of Islamic Banks in Libya: The Mediating Role of Work Engagement', Hamdard Islamicus, 43(1), pp. 25-43.

Ekawati, E. et al. (2019) 'Organization Culture Oriented on Islamic Principle and Company Performance', Review of Integrative Business and Economics Research, 8, pp. 301-312.

ElKelish, W. W. and Rickards, R. C. (2018) 'Organisational culture's impact on management accounting and control practices in the United Arab Emirates', International Journal of Accounting, Auditing and Performance Evaluation, 14(1), pp. 24-46.

Falatehan, I. (2018)). Legal Counsel for the Defendant in Corruption Case Worth IDR 566 Billionin BJB Syariah. Studying the Prosecutor's Indictment. Available at: http://jabar.tribunnews.com (Accessed: 6 January 2019).

Galileoni, G. . and Lestari, R. (2017) 'The 
Effect of Good Corporate Governance Implementation on Company Performance Appraisal', in Proceeding: 1st National Seminar on Small Medium Enterprises Towards the Self Reliance of Micro, Small and Medium Enterprises in Indonesia.

HA, V. D. (2020) 'Impact of organizational culture on the accounting information system and operational performance of small and medium sized enterprises in Ho Chi Minh City', Journal of Asian Finance, Economics, and Business, 7(2), pp. 301-308.

Hilton, R. and Platt, D. (2016) Managerial Accounting Creating Value in a Dynamic Business Environment. 11th edn. New York, United States: McGraw-Hill Education.

Kadir, A. and Muh (2015) Work Ethics in Islamic Perspective. Sulawesi: The Enlightenment Foundation Publisher.

Kasasbeh, F. I. O. (2017) 'Impact of Corporate Governance on the Effectiveness of Accounting Information System in Jordanian Industrial Companies', International Business Research, 10(10), pp. 1-9.

Kuraesin, A. D. (2015) 'Kuraesin, Arlis Dewi', The Influence of Organizational Culture on Management Information System, 4(8), pp. 140-141.

Lam, J. (2017) Implementing Enterprise Risk Management: From Methods to Applications (Wiley Finance). 1st edn. United State of America: John Wiley \& Sons Inc.

Laudon, K. C. and Laudon, J. P. (2020) Management information systems: Managing the digital firm. 16th edn. edn. England: Pearson.

Lestari, R. (2020) 'Analysis of Quality of Management Accounting Information System to Improve the Implementation of Good Corporate Governance Principles (Case of Sharia Commercial Banks in Bandung City)', Research Journal of Finance and Accounting, 11(6), pp. 8589.

Lestari, R., Sofianty, D. and Kuntorini, R. S. (2019) 'Factor Influences on Quality of Management Accounting Information System and its Impact on Good Corporate Governance Implementation', in Proceedings of the 2nd Social and Humaniora Research Symposium. Atlantis Press, pp. 5-8.

Lestari, R., Sofianty, D. and Sukarmanto, E. (2018) 'The Implementation of Good
Corporate Governance: Required Quality of Management Accounting Information System? (Empirical Evidence on Sharia Banking Institutions in Bandung City, Indonesia)', KnE Social Sciences, 3(10), pp. 514-522.

Majid, J. et al. (2020) 'The Influence of Accounting Information Systems and Internal Control on the Quality Of Financial Statement with Intellectual Intelligence as $A$ Moderating Variable ( $A$ Study Oncoffee Shopsin Makassar City)', International Journal of Research Science and Management, 7(3), pp. 1-19.

MAKI (2019) Corruption Case at Bank Syariah Mandiri Simalungun Street in Place, Fajar Indonesia Network. Available at: http:// fin.co.id (Accessed: 5 November 2019).

Mariana, M. and Maria, C. (2016) 'Transparency of accounting information in achieving good corporate governance. True View and Fair Value', Social Sciences and Education Research Review, 3(1), pp. 41-62.

McShane, S. and Glinow, M. A. Von (2017) Organizational behavior. 5th edn. Singapore: McGraw-Hill Education.

Meiryani (2015) 'Influence Business Strategy On The Quality of Accounting Information System', International Journal of Scientific \& Technology Research, 4(2), pp. 80-86.

Musah, A. and Adutwumwaa, M. Y. (2021) 'The effect of corporate governance on financial performance of rural banks in Ghana', International Journal of Financial, Accounting, and Management, 2(4), pp. 305-319.

Napitupulu, I. H. (2015) 'Impact of Organizational Culture on The Quality of Accounting Information System: A Theoretical Approach', Research Journal of Finance and Accounting, 6(4), pp. 7484.

Napitupulu, I. H. (2018) 'Organizational Culture in Management Accounting Information System: Survey on stateowned Enterprises (SOEs) Indonesia Approach', Global Business Review, 19(3), pp. 556-571.

Napitupulu, I. H. (2020) 'Internal Control, Manager's Competency, Management Accounting Information Systems and Good Corporate Governance: Evidence form Rural Banks in Indonesia', Global Business Review, pp. 1-23.

Nasieku, T. and Githinji, N. (2016) 'Use of Strategic Management Accounting By Organizations', Asian Journal of Business 
and Management, 4(4), pp. 165-173.

Novatiani, R. A. et al. (2018) 'The Influence of Business Strategy and Good Corporate Governance on Company's Performance', International Journal of Engineering \& Technology, 7(4.34), pp. 284-286.

Novianty, I. (2019) 'The Quality of Management Accounting Information Systems From User's Ethics, Environmental Uncertainty, And Top Management Support Perspectives (An Empirical Case of Local Government in Indonesia)", South East Asia Journal of Contemporary Business, Economics and Law, 20(1), pp. 1-10.

Nurliyani, N., Darma, J. and Ikhsan, A. (2020) 'he Effect of Organizational Culture on the Quality of Accounting Information Systems', Budapest International Research and Critics Institute (BIRCIJournal): Humanities and Social Sciences, 3(1), pp. 198-205.

Nusa, I. B. S. (2015) 'Influence of organizational culture and structure on quality of accounting information system', International Journal of Scientific \& technology research, 4(5), pp. 257-267.

Pasch, T. (2019) 'Strategy and innovation: the mediating role of management accountants and management accounting systems' use', Journal of Management Control, 30(2), pp. 213-246.

Puspitawati, L. and Susanto, A. (2018) 'Influence of Business Strategy Through the Management Accounting Information System to the Quality of Management Accounting Information - Evidence in Indonesia', in International Conference on Business, Economics, Social Sciences and Humanities (ICOBEST). Atlantis Press, pp. 24-29.

Rachman, G. G., Adrian, M. I. and Husniah, $H$. (2019) 'The influence of technology and organizational culture on the quality of management accounting information systems', in Mulawarman International Conference On Economics and Business, pp. 123-131.

Robbins, S. P. and Judge, A. T. A. (2019) Organizational Behavior. 18th edn. United State of America: Pearson Education Inc.
Romney, M. B. and Steinbart, P. J. (2018) Accounting Information Systems. 14th edn. USA: Pearson.

Saiman, B. (2018) Bank Syariah Mandiri Allegedly Provided Fictitious Financing of Rp. $1.1 \mathrm{~T}$, cnn indonesia. Available at: http://cnnindonesia.com (Accessed: 6 January 2019).

Satria, B. and Yuliansyah, Y. (2020) 'The Influence of Islamic Organizational Culture on Performance with Management Accounting Systems as Mediating Variable', International Journal of Advanced Science and Technology, 29(2), pp. 2128-2150.

Sekaran, U. and Bougie, R. (2016) Research Methods for Business: A Skill-Building Approach. 7th edn. United Kingdom: John Wiley \& Sons Ltd.

Supriyanto, E. (2018) Perbankan Syariah: Kinerja yang Buruk Akibat Tata Kelola, Harian Ekonomi Neraca. Available at: http://neraca.co.id (Accessed: 6 November 2019).

Susanto, A. (2017) Accounting Information Systems: Understanding Integrated Concepts. 1sted edn. Bandung: Lingga Jaya.

Susanto, A. and Meiryani (2018) 'The Influence of Organizational Culture on Quality of Accounting Information Systems Management', Journal of Engineering and Applied Sciences, 13(16), pp. 6639-6644.

Uyar, A., Gungormus, A. H. and Kuzey, C. (2017) 'Impact of the accounting information system on corporate governance: Evidence from Turkish non-listed companies', Australasian Accounting, Business and Finance Journal, 11(1), pp. 9-27.

Wheelen, T. L. et al. (2018) No Title. 16th edn. United State of America: Pearson.

Zaena, R. R. (2016) 'The Effect of Top Management Commitment, Organizational Culture on The Quality of Accounting Information Systems Management and Impact on User Satisfaction', European Journal of Accounting, Auditing and Finance Research, 4(9), pp. 15-29. 